\title{
UPAYA MEMBANGUN KETRAMPILAN BERPIKIR KRITIS MENGGUNAKAN PETA KONSEP UNTUK MEREDUKSI MISKONSEPSI FISIKA
}

\author{
Ridho Adi Negoro, \\ Husnul Hidayah, \\ Ani Rusilowati, \\ Bambang Subali \\ Universitas Negeri Semarang \\ Semarang, Indonesia \\ E-mail: rannegoro@gmail.com
}

\begin{abstract}
Abstrak
Pemahaman konsep pada siswa merupakan korban dari pembelajaran fisika yang hanya menuntut siswa untuk menghafal rumus matematis. Pembelajaran seperti itu berujung pada kasus miskonsepsi materi fisika yang masih banyak menjangkit siswa. Salah satu materi fisika yaitu gerak lurus memiliki banyak persamaan matematis yang digunakan. Tujuan penelitian ini adalah untuk membangun ketrampilan berpikir kritis siswa melalui penggunaan peta konsep sehingga dapat mereduksi miskonsepsi materi gerak lurus. Rancangan penelitian menggunakan penelitian tindakan kelas yang terdiri dari 2 siklus. Masing-masing siklus terdiri dari langkah: perencanaan, implementasi, evaluasi dan refleksi yang mengadopsi model spiral dari Kemmis dan MC Taggart. Pada saat pelaksanaan pembelajaran, siswa diberikan peta konsep yang berkaitan dengan konsep yang harus dikuasai. Hasil penelitian ini adalah sebagai berikut 1) terjadi peningkatkan ketrampilan berpikir kritis pada siswa kelas X SMA melalui pembelajaran menggunakan Peta Konsep dengan nilai rata-rata tes essai keterampilan berpikir kritis kelas setelah CAR 85,2 dan ketuntasan berdasarkan indikator sebesar 88,2\%. 2) Terjadi reduksi miskonsepsi materi Gerak Lurus pada siswa kelas X SMA melalui pembelajaran menggunakan Peta Konsep ditunjukan oleh nilai rata-rata tes essai setelah CAR sebesar 82,5.
\end{abstract}

Kata Kunci: Berpikir kritis, peta konsep, miskonsepsi, gerak lurus.

\begin{abstract}
Conceptual understanding of students is a victim of physics learning which only requires students to memorize mathematical formulas. Learning like that leads to cases of misconceptions of physical material that still infect students. One of the physical materials, namely straight motion, has many mathematical equations used. The purpose of this study is to build students' critical thinking skills through the use of concept maps so as to reduce misconceptions of straight motion material. The research design uses classroom action research consisting of 2 cycles. Each cycle consists of steps: planning, implementation, evaluation and reflection which adopt a spiral model from Kemmis and Mc Taggart. During the implementation of learning, students are given a concept map related to concepts that must be mastered. The results of this study are as follows: 1) there is an increase in critical thinking skills in class X high school students through learning using Concept Maps with an average essay test of critical thinking skills in class after CAR 85.2 and completeness based on indicators of $88.2 \%$. 2) There was a reduction in misconceptions of Straight Motion material for class X high school students through learning using Concept Maps shown by the average value of essay tests after the CAR of 82.5 .
\end{abstract}

Keywords: Critical thinking, concept map, misconception, straight motion.

\section{PENDAHULUAN}

Fisika merupakan ilmu yang mempelajari tentang fenomena alam, salah satunya terkait dengan gerak suatu benda. Fenomena alam dibentuk oleh interaksi berbagai besaran fisis. Dalam membentuk fenomena alam satu atau lebih besaran fisis saling berhubungan dan saling berinteraksi. Siswa memperoleh pengetahuan fisis tentang suatu objek berdasarkan pengalaman mereka melalui pengindraan. Dari hal tersebut akan 
menimbulkan pandangan oleh masing-masing siswa yang mungkin berbeda.

Miskonsepsi dan Ketrampilan Berpikir Kritis Pandangan siswa terhadap fenomena alam mungkin saja tidak sesuai dengan apa yang sesungguhnya terjadi. Hal tersebut merupakan suatu bentuk ketidaksesuaian pemahaman siswa terhadap suatu fenomena dengan makna sesungguhnya atau yang biasa disebut miskonsepsi

Adanya miskonsepsi siswa di Indonesia juga disebabkan oleh adanya buku yang dijual dipasaran selain itu juga proses pembelajaran Fisika yang dilakukan guru di kelas masih menerapkan belajar hanya menghafalkan konsep-konsep semata dalam prosesnya, bukan belajar bermakna dengan menemukan sendiri konsep-konsepnya. Akibatnya baik guru dan siswa yang menggunakan buku itu akan mengalami adanya miskonsepsi.

Berpikir kritis adalah proses metakognitif yang melalui penilaian reflektif yang bertujuan, meningkatkan peluang menghasilkan kesimpulan logis untuk argumen atau solusi untuk masalah. Instruksi dalam berpikir kritis menjadi sangat penting karena memungkinkan individu untuk mendapatkan pemahaman yang lebih kompleks tentang informasi yang mereka temui dan promosikan pengambilan keputusan yang baik dan pemecahan masalah dalam aplikasi dunia nyata (Butler et al, 2012). Menurut Ennis ketrampilan berpikir kritis dilkelompokan menjadi lima indikator, yaitu (1) memberi penjelasan sederhana (elementary clarification), (2) membangun ketrampilan dasar (basic support) (3) membuat inferensi (inference), (4) memberi penjelasan lanjut (advanced clarification), dan (5) mengatur strategi dan taktik (Strategies and tactics) (Ennis, 2005).

Ketrampilan berpikir kritis dapat dilatihkan kepada siswa melalui pembiasaan berpikir dengan belajar bernalar, dengan cara tersebut diperlukan keterlibatan aktivitas pemikir sendiri. Salah satu pendekatan dalam mengembangkan ketrampilan berpikir kritis, dengan memberi sejumlah pertanyaan, sambil membimbing dan mengaitkan pada konsep yang dimiliki siswa

Dari uraian tentang miskonsepsi dan ketrampilan berpikir kritis dapat dilihat bahwa keduanya sangat erat kaitannya yaitu terfokus pada konsep. Konsep dalam pembelajaran harus dihadirkan melalui pendekatan fenomena yang melekat dengan keseharian siswa. Pembelajaran yang menitikberatkan pada konsep yang lebih disederhanakan dan mengeksplorasi penalaran dari siswa agar mereka dapat lebih mendalami suatu konsep dalam pembelajaran fisika (Sarwi, 2016).

Menurut Ausubel sebagaimana dikutip dalam Dahar (1989), pembelajaran bermakna merupakan suatu proses yang mengaitkan antar informasi baru pada konsep-konsep yang relevan yang terdapat pada struktur kognitif seorang siswa. Hal ini yang diharapkan melalui proses pembelajaran bermakna tersebut dapat membuat pemahaman konsep siswa menjadi lebih baik dan tidak terjadi miskonsepsi terhadap suatu konsep.

Multirepresentasi Pengetahuan Menggunakan Peta Konsep Multirepresentasi dapat dijadikan sebagai pendekatan dalam pembelajaran Fisika. Tampilan berbagai representasi dalam penanaman suatu konsep diprediksi akan dapat lebih membantu peserta didik dalam memahami konsep yang dipelajari. Hal ini terkait dengan setiap peserta didik (siswa atau mahasiswa) memiliki kemampuan spesifik yang lebih menonjol dibanding kemampuan lainnya. Penggunaan multirepresentasi dapat melengkapi kekurangan suatu pemahaman dari suatu representasi pembelajaran yang biasa digunakan, karena dalam materi pembelajaran memungkinkan adanya kebutuhan representasi lain (Lasry dan Aulls, 2007). Hal ini mudah ditemukan dalam pembelajaran fisika, dimana selain pemahaman matematis yang dibutuhkan, pemahaman konsep dari fenomena fisika harus dikuasai. Maka dari itu, dibutuhkan suatu multirepresentasi sebagai salah satu strategi dalam mengatasi miskonsepsi.

Salah satu representasi pengetahuan yang dapat digunakan untuk mengatasi miskonsepsi siswa adalah dengan menggunakan peta konsep. Peta konsep adalah diagram yang menunjukkan hubungan antar konsep. Peta konsep memiliki fungsi sebagai alat grafis untuk mengatur dan merepresentasikan pengetahuan dan instrumen yang membantu mengatur dan menata pengetahuan. Salah satu keuntungan besar menggunakan peta konsep adalah selama proses formulasinya dapat mengkonsolidasikan pemahaman yang konkret dan tepat tentang makna dan hubungan antar konsep. Dengan demikian belajar menjadi suatu proses aktif, bukan yang pasif (Jack, 2013). Pernyataan sesuai dengan teori belajar Ausubel. Berdasarkan teori belajar Ausubel guru harus menguasai konsep-konsep dan menghadirkannya dalam pembelajaran supaya belajar bermakna dapat berjalan dengan baik. Peta konsep melalui pendekatan multirepresentasi merupakan salah satu bentuk upaya untuk mempermudah siswa dalam memahami suatu konsep, khususnya dalam pembelajaran Fisika. Hal ini dapat memenuhi kebutuhan siswa untuk memahami suatu konsep dimana representasi yang disajikan lebih bervariasi namun tidak lepas dari konsep itu sendiri. Oleh sebab itu, penggunaan peta konsep dengan pendekatan multirepresentasi diharapkan efektif dalam menciptakan pengetahuan bermakna, menggambarkan dan meminimalisir kesalahpahaman konsep, dan menelusuri perubahan konseptual siswa dalam memahami suatu konsep untuk mereduksi miskonsepsi pada siswa.

Temuan di lapangan dari hasil observasi dan data ulangan harian siswa kelas 10 SMAN 8 Semarang yang berjumlah 39 siswa, Pengajaran masih menggunakan metode ceramah hal ini memiliki kelemahan yaitu guru sulit untuk mengontrol setiap siswa agar bisa menguasai konsep karena jumlah siswa yang tergolong banyak. Selain itu, metode ceramah yang dilakukan guru tidak mengahasilkan ketrampilan berpikir kritis pada siswa karena tidak adanya interaksi dan keaktifan siswa untuk menggali pengetahuan. Wawancara kepada siswa menggambarkan bahwa banyak siswa yang mengharapkan metode pembelajaran lain dan semua siswa mengalami miskonsepsi pada materi gerak lurus. Hal ini diperkuat dengan hasil ulangan harian siswa dimana semua siswa tidak mencapai nilai KKM (kriteria ketuntasan minimal). Dari hasil temuan ini, peneliti termasuk guru kelas berupaya mengatasi masalah ini 
dengan membangun ketrampilan berpikir kritis untuk mereduksi miskonsepsi siswa pada materi gerak lurus .

Tujuan dari penelitian ini adalah 1) untuk meningkatkan ketrampilan berpikir kritis pada siswa kelas X SMA, 2) untuk mereduksi miskonsepsi pada siswa kelas X SMA materi kinematika gerak sub bab GLB dan GLBB.

\section{METODE}

Metode Penelitian yang dipilih pada penelitian ini adalah Penelitian Tindakan Kelas, dengan subjek penelitian adalah 39 siswa kelas XI IPA. Tempat penelitian adalah di kelas $\mathrm{X}$ MIPA di SMAN 8 Semarang.
Waktu penelitian dilaksanakan pada semester ganjil tahun akademik 2017/2018 selama kurang lebih 1 bulan efektif. Data pada penelitian ini diperoleh dari hasil observasi terhadap keterampilan berpikir kritis siswa, untuk mengetahui sejauh mana reduksi miskonsepsi dicapai siswa pada penelitian ini dilakukan tes essai. Data yang diperoleh dianalisis kemudian dideskripsikan atau dijabarkan dalam bentuk deskriptif kualitatif.

Penelitian ini dilakukan 2 siklus yang masingmasing siklus terdiri dari langkah perencanaan, implementasi, evaluasi dan refleksi yang mengadopsi Model Spiral dari Kemmis dan MC Taggart.

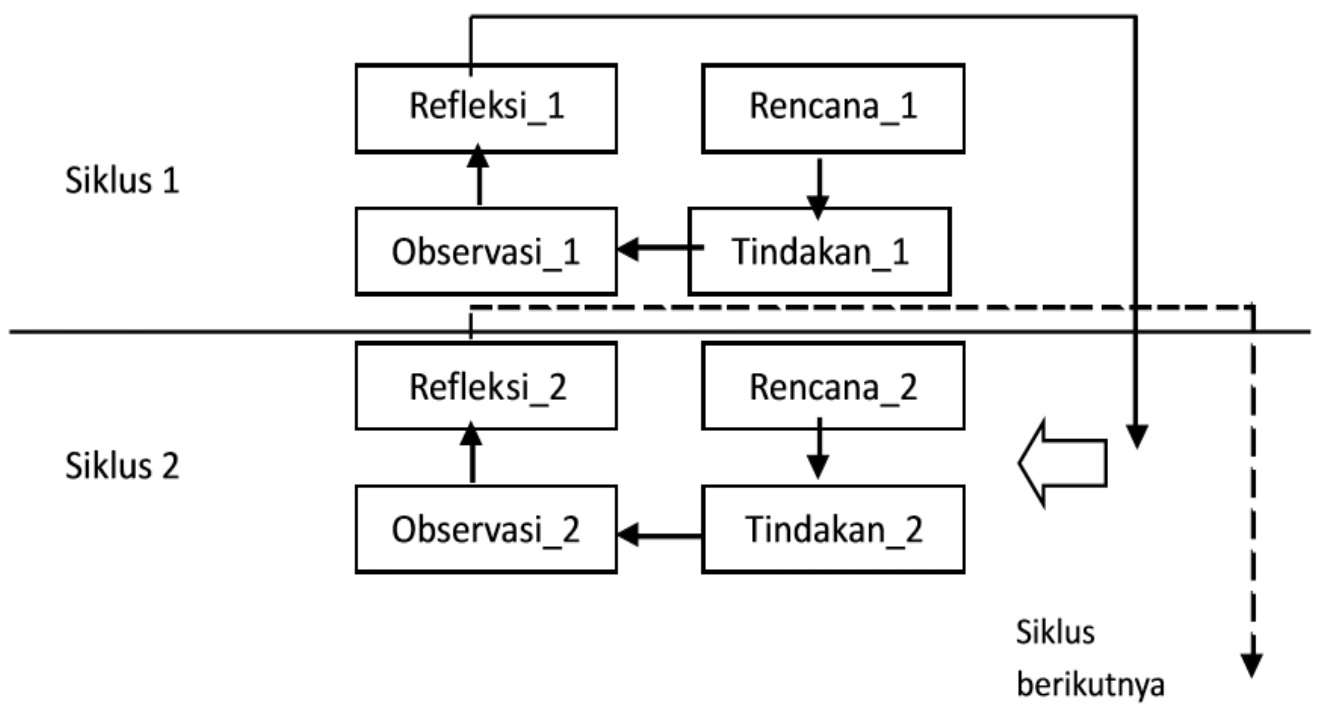

Gambar 1. Desain PTK menurut Kemmis dan MC Taggart.

Tabel 1. Indikator Ketrampilan berpikir kritis

\begin{tabular}{|c|c|c|c|}
\hline No & $\begin{array}{l}\text { Aspek Keterampilan Berpikir } \\
\text { Kritis }\end{array}$ & Indikator & Sub-Indikator \\
\hline \multirow[t]{5}{*}{1.} & Memberi penjelasan sederhana & $\begin{array}{l}\text { Bertanya dan menjawab } \\
\text { pertanyaan }\end{array}$ & $\begin{array}{l}\text { 1. Merumuskan pertanyaan } \\
\text { 2. Menjawab pertanyaan dengan logis }\end{array}$ \\
\hline & & & $\begin{array}{l}\text { 3. Memberi contoh } \\
\text { 4. Menjawab pertanyaan mengapa } \\
\text { 5. Menghubungkan suatu konsep }\end{array}$ \\
\hline & & Mengemukakan Argumen & 1. Mengkonstruksi argument \\
\hline & & & 2. Merefleksi argumen \\
\hline & & & 3. Melakukan revisi terhadap argumen \\
\hline \multirow[t]{6}{*}{2.} & Membangun keterampilan dasar & $\begin{array}{l}\text { Membandingkan hasil } \\
\text { pengamatan dengan referensi }\end{array}$ & $\begin{array}{l}\text { 1. Membandingkan hasil pengamatan } \\
\text { dengan referensi yang digunakan }\end{array}$ \\
\hline & & & $\begin{array}{l}\text { 2. Mengkonstruksi alasan apabila hasil } \\
\text { pengamatan berbeda dengan referensi }\end{array}$ \\
\hline & & & $\begin{array}{l}\text { 3. Mempertimbangkan apakah sumber } \\
\text { dapat dipercaya atau tidak. }\end{array}$ \\
\hline & & Mengobservasi dan & 1. Melaporkan hasil observasi \\
\hline & & $\begin{array}{c}\text { mempertimbangkan laporan } \\
\text { observasi }\end{array}$ & 2. Merekam hasil observasi \\
\hline & & & 3. Menanggapi hasil observasi \\
\hline \multirow[t]{2}{*}{3.} & Membuat inferensi & Menginduksi dan & 1. Menyusun hipotesis \\
\hline & & $\mathrm{m}$ & $\begin{array}{l}\text { 2. Menemukan persamaan dan perbedaan } \\
\text { untuk membuat kesimpulan }\end{array}$ \\
\hline
\end{tabular}




\begin{tabular}{|c|c|c|c|}
\hline No & $\begin{array}{c}\text { Aspek Keterampilan Berpikir } \\
\text { Kritis }\end{array}$ & Indikator & Sub-Indikator \\
\hline \multirow{4}{*}{4.} & \multirow{4}{*}{ Memberi penjelasan lanjut } & \multirow{4}{*}{ Strategi pemecahan masalah } & $\begin{array}{l}\text { Mengidentifikasi fenomena untuk } \\
\text { membuat kesimpulan }\end{array}$ \\
\hline & & & 1. Merumuskan masalah \\
\hline & & & $\begin{array}{l}\text { 2. Merumuskan alternatif-alternatif } \\
\text { keputusan menyelesaikan masalah }\end{array}$ \\
\hline & & & 3. Menentukan keputusan yang diambil \\
\hline
\end{tabular}

\section{Siklus I}

\section{Rencana 1:}

1. Berdasarkan pada rumusan masalah akan diterapkan model pembelajaran

2. Menggunakan Peta Konsep dengan metode demonstrasi.

3. Dipilih pokok bahasan yang sesuai dengan materi yang diajarkan yakni Kinematika Gerak

4. Direncanakan RPP untuk pokok bahasan tersebut secara terperinci.

5. Dirancang skenario pelaksanaan pembelajaran mengunakan Peta

6. Konsep dalam pembelajaran siklus 1

7. Disiapkan bahan dan media pembelajaran yang akan digunakan, serta dokumen yang lain, seperti

daftar hadir, alat demonstrasi, lembar kerja siswa, dll.

8. Merancang instrumen untuk mengamati proses pembelajaran dan hasil belajar serta panduan menganalisisnya.

9. Menyiapkan rekan sejawat untuk bertindak sebagai observer aktivitas berpikir kritis siswa, dan membantu mendokumentasikan kegiatan.

\section{Tindakan 1 :}

1. Mengajar selama 2 JP pada pertemuan dengan pokok bahasa Kinematika Gerak yang terdiri dari GLB dan GLBB.

2. Pembelajaran dioptimalkan agar sesuai dengan skenario yang telah ditetapkan.

3. Mendokumentasikan (mengumpulkan dokumen kegiatan siswa, dan dokumen yang lain) dan mengobservasi semua kegiatan yang dilakukan dalam proses pembelajaran.

\section{Observasi 1 :}

\section{HASIL DAN PEMBAHASAN}

\section{Hasil Penelitian}

Hasil Penelitian dapat disajikan dengan tabel dan grafik berikut ini :
1. Melakukan pengamatan terhadap proses pembelajaran dan respon kelas, serta siswa dengan memakai instrumen yang telah disiapkan.

2. Meminta rekan sejawat untuk mengamati proses mengajar yang dilakukan guru dengan memakai lembar observasi yang telah dirancang.

3. Melakukan pengamatan hasil belajar dengan menggunakan tes, wawancara, atau instrumen lain yang telah disiapkan.

4. Menghimpun semua hasil pengamatan dan menganalisisnya.

\section{Refleksi 1}

1. Mendeskripsikan indikator kerja yang telah tercapai.

2. Berdasarkan hasil analisis pengamatan (baik proses maupun hasil pembelajaran) melakukan evaluasi terhadap indikator kerja yang belum tercapai.

3. Mengetahui kekurangan dari penerapan pembelajaran menggunakan Peta Konsep.

4. Hasil refleksi tersebut dihimpun dan dirangkum sebagai masukan dalam perancangan siklus ke II

Untuk menganalisis data hasil observasi keterampilan berpikir kritis siswa yang mengacu indikator di atas, digunakan rumus :

$$
S_{a}=\frac{S}{S_{m}} \times 100 \%
$$

(Arikunto, 2002)

\section{Keterangan :}

Skor dihitung dalam persentase (\%)

Skor maksimum $=21$

$S_{\varangle}:$ Skor indikator ketrampilan berpikir kritis dalam \%

$S$ : Skor indikator yang diperoleh

$S_{m}$ : Skor maksimum

Tabel 2. Hasil penilaian ketrampilan berpikir kritis dalam proses pembelajaran

\begin{tabular}{ccccl}
\hline No. & Jenis penilaian & Siklus 1 & Siklus 2 & \multicolumn{1}{c}{ Keterangan } \\
\hline 1. & Ketrampilan berpikir kritis & $68,6 \%$ & $88,2 \%$ & $\begin{array}{l}\text { Siklus 1 : 2 2 Siswa belum tuntas } \\
\text { Siklus 2 : Seluruh Siswa tuntas }\end{array}$ \\
\hline
\end{tabular}




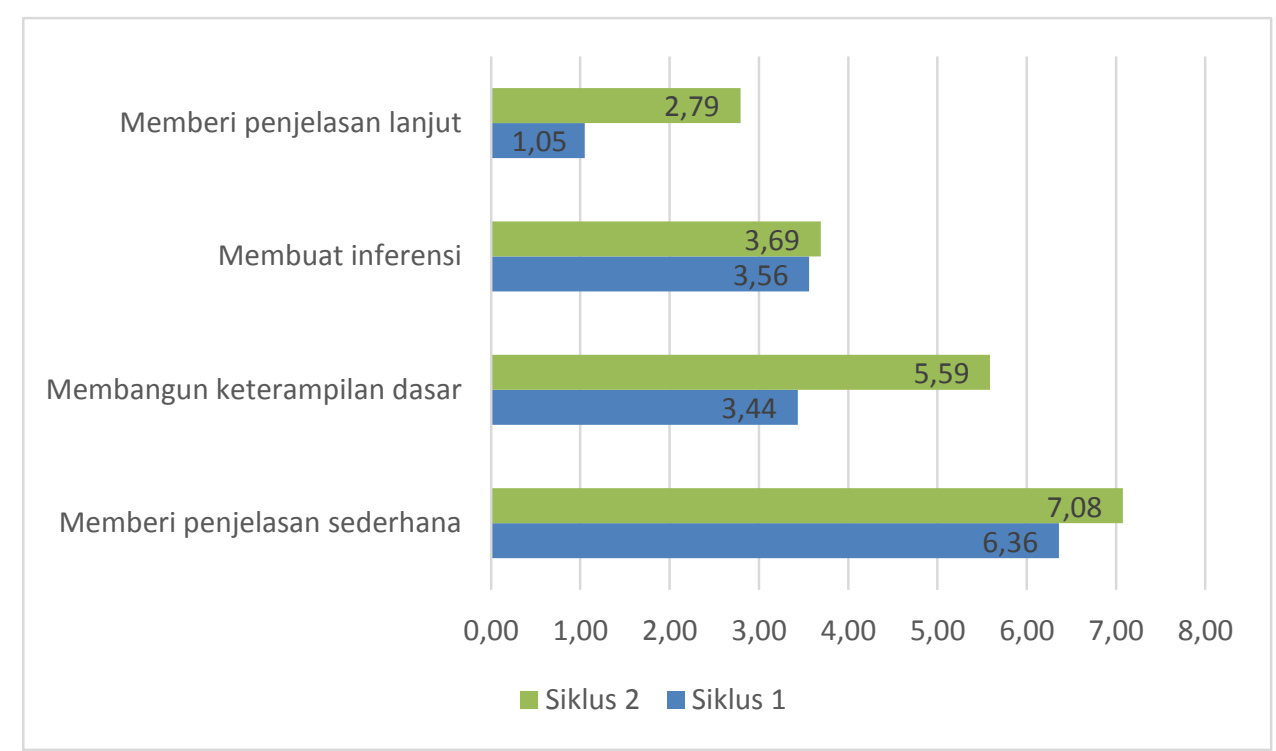

Gambar 1. Grafik penilaian ketrampilan berpikir kritis dalam proses pembelajaran

Tabel 3. Nilai rata-rata tes essai

\begin{tabular}{|c|c|c|c|c|c|}
\hline \multirow[t]{2}{*}{ No. } & \multirow[t]{2}{*}{ Jenis penilaian } & \multirow{2}{*}{$\begin{array}{l}\text { Sebelum } \\
\text { CAR }\end{array}$} & \multicolumn{2}{|c|}{$\begin{array}{c}\text { Setelah CAR } \\
\text { Siklus }\end{array}$} & \multirow[t]{2}{*}{ Keterangan } \\
\hline & & & 1 & 2 & \\
\hline 1. & $\begin{array}{l}\text { Keterampilan } \\
\text { berpikir kritis }\end{array}$ & 26,7 & 55,6 & 85,2 & $\begin{array}{c}\text { Sebelum CAR : Tidak ada siswa yang } \\
\text { tuntas } \\
\text { Siklus 1: } 33 \text { Siswa belum tuntas } \\
\text { Siklus } 2: \text { Seluruh Siswa tuntas }\end{array}$ \\
\hline 2. & Miskonsepsi & 28,4 & 59,7 & 82,5 & $\begin{array}{c}\text { Sebelum CAR : Tidak ada siswa yang } \\
\text { tuntas } \\
\text { Siklus } 1: 26 \text { Siswa belum tuntas } \\
\text { Siklus } 2: \text { Seluruh Siswa tuntas }\end{array}$ \\
\hline
\end{tabular}

Ket : Ketuntasan tes essai miskonsepsi dan ketrampilan berpikir kritis $>70$

\section{Pembahasan}

Siswa dalam pembelajaran fisika di sekolah memiliki kecenderungan menganggap fisika dipenuhi rumus yang sulit untuk dipahami, lebih daripada itu banyak dari mereka yang tidak dapat menghubungkan antara pembelajaran fisika dengan fenomena kehidupan di sekitar mereka. Pembahasan fisika berfokus hanya pada matematisnya adalah hal yang menjadi sebuah usaha guru yang berupaya agar siswa mampu mengerjakan soal fisika yang matematis. Kondisi tersebut memiliki efek terhadap pengetahuan yang mereka dapat, dimana terdapat cacat pengetahuan yang bisa dikhususkan dengan istilah miskonsepsi.

Peta konsep merupakan representasi pengetahuan yang dapat menyederhanakan pemahaman siswa terhadap suatu materi pembelajaran. Pemilahan hal pokok menjadi fokus penting dalam peta konsep dan upaya menghubungkan tiap pokok dengan fenomena alam sekitar yang dekat dengan siswa adalah bahan untuk membentuk ketrampilan berpikir kritis pada siswa, dimana selanjutnya dengan ketrampilan berpikir kritis maka siswa akan mampu mereduksi miskonsepsi mereka terhadap materi fisika.

Sebelum pelaksanaan penelitian, siswa diberikan sebuah tes uji berbentuk essai untuk mengetahui kemampuan berpikir kritis mereka dan sejauh mana terjadinya miskonsepsi pada materi gerak lurus. Hasil essai berdasarkan tabel 3 menunjukan bahwa tidak ada siswa yang tuntas dalam tes essai tersebut. Hasil tersebut memberikan pandangan bahwa terdapat kesalahan pemberian pembelajaran.

Perbaikan pembelajaran dilakukan dengan menggunakan peta konsep oleh guru. Dalam pembelajaran siswa dibentuk kelompok untuk mendiskusikan persoalan yang diangkat dalam pembelajaran melalui peta konsep. Setiap kegiatan yang dilakukan oleh siswa diberikan perhatian oleh observer untuk dicatat dan diketahui sejauh mana ketrampilan berpikir kritis mereka. Hasil yang tergambar pada gambar 1 menunjukan bahwa terjadi peningkatan rata- 
rata ketrampilan berpikir siswa di setiap aspek dari siklus 1 hingga siklus 2 .

Pada siklus 1 dilakukan pembelajaran menggunakan peta konsep guna membangun ketrampilan berpikir kritis pada siswa. Ketrampilan berpikir kritis dikembangkan agar siswa mampu mereduksi miskonsepsi mereka pada materi gerak lurus. Proses pembelajaran dilakukan dengan membagi siswa kedalam 6 kelompok yang kemudian mereka mendiskusikan beberapa persoalan yang diberikan oleh guru melalui demonstrasi dan tanya jawab langsung. Pada siklus ini, proses CAR masih belum maksimal dikarenakan banyak siswa yang masih belum siap dengan proses pembelajaran yang baru. Hal ini ditunjukan dengan ketidakantusiasan siswa menjawab beberapa pertanyaan dan persoalan langsung dari guru. Hasil pada tabel 3 menunjukan hasil tes essai yang diberikan setelah siklus 1 dimana tes ketrampilan berpikir kritis terdapat 33 siswa yang tidak tuntas dan tes miskonsepsi terdapat 26 siswa yang tidak tuntas. Berdasarkan siklus 1, peneliti merefleksi kekurangan dalam kesiapan siswa melakukan pembelajaran.

Berdasarkan tabel 2, pada siklus 2 siswa mengalami peningkatan ketrampilan berpikir kritis. Peningkatan tersebut muncul karena siswa lebih siap melakukan pembelajaran dibandingkan dengan pembelajaran pada siklus 1. Menurut Einav Aizikovitsh (2010) ketrampilan berpikir kritis dapat dihasilkan melalui pendekatan yang tepat, yaitu guru mampu menyajikan langkah pembelajaran yang spesifik menghasilkan ketrampilan berpikir kritis. Dari temuan di lapangan, agar ketrampilan berpikir kritis dapat dimiliki, siswa harus memiliki rasa keingintahuan (curiosity). Hal inilah yang harus direkayasa oleh guru dalam melakukan pembelajaran siswa agar siap dan dapat masuk ke suasana pembelajaran yang diharapkan oleh guru yang selanjutnya akan mengantarkan siswa memiliki keterampilan berpikir kritis.

Hasil tes essai yang diberikan pada siswa setelah dilakukan CAR (Class Action Research) pada siklus 2 menunjukan bahwa seluruh siswa telah tuntas dalam tes ketrampilan berpikir kritis dengan nilai ratarata 85,2 dan tes miskonsepsi dengan nilai 82,5 . Hasil tersebut memberikan gambaran bahwa proses pembelajaran yang telah dilakukan dapat membentuk ketrampilan berpikir krtitis siswa sehingga miskonsepsi pada materi gerak lurus terduksi.

Dari uraian hasil di atas dapat diketahui bahwa peta konsep dapat meningkatkan ketrampilan berpikir kritis yang pada akhirnya mereduksi miskonsepsi pada materi gerak lurus. Hal ini terjadi karena terdapat peningkatan kualitas pembelajaran di kelas, sesuai dengan penelitian a Heinze-Fry \& Novak (1990). Dari hasil penelitian juga dapat dilihat bahwa peta konsep juga efektif digunakan dalam pembelajaran fisika dengan konsep yang sulit dikuasai oleh siswa, penelitian lain yang sesuai yaitu Karakuyu (2010) dan Jack (2013). Penelitian Nugroho (2017) menjelaskan bahwa media dapat meningkatkan kemampuan berpikir kritis siswa, hal ini bersesuaian dengan peta konsep yang digunakan dalam penelitian ini sebagai media pembelajaran siswa sehingga dapat meningkatkan pemahaman konsep pada siswa.

Pada dasarnya sebuah pembelajaran memiliki kekurangan seperti pembelajaran di kelas pada penelitian ini yang diakibatkan berbagai kendala diantaranya yaitu :

1. Ketidaksiapan siswa di awal pembelajaran (siklus 1) sehingga kelancaran pembelajaran terganggu digambarkan dengan interaksi guru dengan siswa yang kurang dan respons siswa yang lambat.

2. Kebiasaan pembelajaran tidak membangun keaktifan dan motivasi siswa membuat siswa malas untuk mengikuti pembelajaran

\section{SIMPULAN}

Berdasarkan hasil analisis data penelitian, maka dapat disimpulkan sebagai berikut :

1. Terjadi peningkatkan ketrampilan berpikir kritis pada siswa kelas X SMA melalui pembelajaran menggunakan Peta Konsep sehingga mampu mengatasi permasalahan pemahaman siswa terkait materi gerak lurus menjadi lebih baik. Hal ini dapat dilihat dari nilai ketuntasan siswa dalam tes essai yang mencapai $100 \%$.

2. Terjadi reduksi miskonsepsi materi Gerak Lurus pada siswa kelas X SMA melalui pembelajaran menggunakan Peta Konsep. Pembelajaran menggunakan peta konsep dapat meningkatkan ketrampilan berpikir kritis siswa sehingga miskonsepsi materi Gerak Lurus pada siswa dapat tereduksi. Ketrampilan berpikir kritis sebagai basis dalam memahami suatu fenomena alam

\section{DAFTAR PUSTAKA}

Ainsworth, S. 2006. DeFT: A conceptual framework for considering learning with multiple representations, Learning and instruction. Journal Learning and Instruction, 16 (3): 183198

Butler, H., Dwyer, C., Hogan, M., Franco, A., dan Almeida, L. 2012. Extending the validity of Halpern critical thinking assessments: Crossnational applications. Thinking Skills and Creativity, 7: 112-121.

Cascini, K dan Anne, R. 2007. Developing Critical Thinking Skills In The Intermediate Accounting Class: Using Simulations With Rubrics. Journal of Business Case Studies, 3 (2): 17-28

Dahar, W. 1989. Teori teori belajar. Bandung: Erlangga

Aizikovitsh, E. dan M. Amit. 2010. Evaluating an infusion approach to the teaching of critical thinking skills through mathematics. ProcediaSocial and Behavioral Sciences, 2(2): 38183822.

Ennis, R.H. and Millman, J. 2005. Cornell critical thinking test, level X (Fifth Edition). Seaside, CA: The Critical Thinking Company. 
Gall, M.D., Gall, JP and Borg, W.R. 2003. Educational Research and Introduction. Seventh Edition. Allyn and Bacon : Boston

Heinze-Fry, J.A. \& Novak, J.D. 1990. Concept Mapping Brings Long Term Movement Towards Meaningfull Learning. Science Education, 74(4): $461-472$

Jack, G. U. 2013. Concept mapping and guided inquiry as effective techniques for teaching difficult concepts in chemistry: effect on students' academic achievement. Journal of Education and Practice, 4(5): 9-15.

Karakuyu, Y. 2010. The effect of concept mapping on attitude and achievement in a physics course. International Journal of Physical Sciences, 5(6): 724-737.

Lasry, N. \& Aulls, M.W. 2007. The effect of multiple internal representation on context-rich instruction. Americans Journal of Physics, 75(11): 1030-1037

Novak, J. D., \& Gowin, D. B. 1984. Learning how to learn. Cambridge University Press.

Nugroho, R., \& Setyawati, R. T. 2017. Penggunaan Media Kancing Magnetik Untuk Meningkatkan Kemampuan Berpikir Kritis Siswa Materi Perkalian Bilangan Bulat. Jurnal Pendidikan (Teori dan Praktik), 1(2).

Sarwi. 2016. Pembelajaran Inovatif Fisika Aktif dan Menyenangkan. Unnes Press : Semarang

Solso, Robert L \& Maclin. 2002. Psikologi Kognitif edisi kedelapan. Erlangga : Jakarta

Suparno, Paul. 2005. Miskonsepsi dan Perubahan Konsep dalam Pendidikan Fisika. Grasindo : Jakarta. 